\title{
Development and application of an immunoassay diagnostic technique for studying Hematodinium infections in Nephrops norvegicus populations
}

\author{
G. D. Stentiford*, D. M. Neil, G. H. Coombs
}

Institute of Biomedical and Life Sciences, University of Glasgow, Glasgow G12 8QQ, Scotland, United Kingdom

\begin{abstract}
Patent Hematodinium infections of the Norway lobster Nephrops norvegicus can be detected with a morphological method (pleopod diagnosis), but this fails to identify low-level haemolymph (sub-patent) and any tissue-based (latent) infections. The current study describes the development and application of an immunoassay for the detection of antigens of the parasite Hematodinium in the Norway lobster $N$. norvegicus. Infected tissue and haemolymph samples were detected as multiple-band reactions to a polyclonal antibody (anti-Hematodinium). The sensitivity limit of the method was 204 parasites $\mathrm{mm}^{-3}$, approximately 10 times more sensitive than the pleopod diagnosis method. Use of the immunoassay on tissue samples taken from catches in the Clyde Sea area, Scotland, UK, showed that the pleopod method considerably under-diagnosed infection prevalence in the early part of the season, though this under-diagnosis decreased as infected lobsters in the field progressed from latent and sub-patent to patent infections. However, the immunoassay failed to detect any infected lobsters during the summer months, suggesting that infection may not be carried over from one season to the next. The data presented suggest that this immunoassay allows for the accurate estimation of Hematodinium infection prevalence in the field and should be employed, where possible, for the routine monitoring of infection prevalence in $N$. norvegicus.
\end{abstract}

KEY WORDS: Hematodinium · Infection prevalence $\cdot$ Nephrops norvegicus $\cdot$ Seasonality $\cdot$ Western blot Resale or republication not permitted without written consent of the publisher

\section{INTRODUCTION}

The Norway lobster Nephrops norvegicus is the subject of an important fishery in the northeast Atlantic, with annual landings in excess of $60000 \mathrm{t} \mathrm{yr}^{-1}$ (Tuck et al. 1997). An infection of $N$. norvegicus by the parasitic dinoflagellate Hematodinium was first described in Scottish populations by Field et al. (1992), and since this initial description Hematodinium infection has also been reported from populations in the Irish Sea (McAliskey \& Briggs 1997), the German Bight

\footnotetext{
*Present address: Centre for Environment, Fisheries and Aquaculture Science (CEFAS), Weymouth Laboratory, Barrack Road, The Nothe, Weymouth, Dorset DT4 8UB, United Kingdom. E-mail: g.d.stentiford@cefas.co.uk
}

(F. Redant pers. comm.) and the Swedish Skagerrak and Kattegat (M. Ulmestrand pers. comm.). It remains to be determined whether this infection extends to $N$. norvegicus populations at more southerly locations along the coastline of mainland Europe and in the Mediterranean Sea.

External manifestations of Hematodinium infection of Nephrops norvegicus include an opaque, vividly coloured carapace, general morbidity (Field \& Appleton 1995), a reduction in swimming performance (Stentiford et al. 2000a) and altered burrow-related behaviour patterns (Stentiford et al. 2001a), while internal pathological effects include marked changes in host physiology (Taylor et al. 1996) and biochemistry (Stentiford et al. 1999, 2000b). These pathological effects are similar to those caused by Hematodinium 
infections of other crustacean host species (Meyers et al. 1987, Hudson \& Shields 1994, Messick 1994, Hudson 1995, Love et al. 1996, Shields \& Squyars 2000). A tentative life-cycle of the $N$. norvegicus isolate of Hematodinium has been described from in vitro cultivation and observations on aquarium-held lobsters (Appleton \& Vickerman 1998), although transmission to uninfected hosts has not been demonstrated to date. In addition, the seasonal nature of Hematodinium infection in $N$. norvegicus has been described in a number of studies (Field et al. 1992, 1998) and has recently been examined in detail for a single fishing ground in the Clyde Sea area, Scotland, UK (Stentiford et al. 2001b).

A number of methods are available for the detection of Hematodinium infection in Nephrops norvegicus. The simplest involves external assessment of the altered carapace colouration and opacity, which can be performed rapidly in the field. However, this method is relatively insensitive, especially for detecting early infections (Stentiford et al. 2001b). The method that has been used most routinely is the pleopod staging technique of Field \& Appleton (1995). This method assigns an infection severity score based on a 4 point scale, which allows the progression of infection to be followed over its seasonal cycle (Field et al. 1992, 1998) and has greatly facilitated laboratory studies on the pathological progression of infection (Stentiford et al. 1999, 2000b). This method, which scores only patent infection, fails to identify latent (tissue-based) and sub-patent (low-level haemolymph parasitaemia) infections and so is likely to underestimate prevalence.

Diagnostic methods based on molecular technology have facilitated the sensitive diagnosis of important pathogens of aquatic hosts. An indirect fluorescence antibody technique (IFAT), developed using antibodies raised against in vitro cultured Hematodinium parasites originally isolated from Nephrops norvegicus, has revealed that some apparently uninfected $N$. norvegicus in fact harbour latent or sub-patent infections outside of the main infection season (Field \& Appleton 1996). However, the epidemiology of these low-level infections and their progression towards patent infections (detectable using the pleopod method) were not undertaken. The current study aimed to develop the IFAT technique of Field \& Appleton (1996) into an immunoblotting assay, and to apply this assay to the analysis of infection in a major $N$. norvegicus fishery over a 12 mo period. Hepatopancreatic tissue was chosen as the study tissue as this has been suggested as a likely location of latent Hematodinium infection in $N$. norvegicus (Field \& Appleton 1996) and is well perfused with haemolymph, and so allows detection of sub-patent as well as latent infections.

\section{MATERIALS AND METHODS}

Capture of lobsters. Norway lobsters Nephrops norvegicus were caught using 90 min tows of a standard otter-trawl (70 mm mesh size) from a depth of approximately $80 \mathrm{~m}$, at a location immediately south of Little Cumbrae (LC) in the Clyde Sea area $\left(55.41^{\circ} \mathrm{N}\right.$, $\left.4.56^{\circ} \mathrm{W}\right)$. The start of the towing period was always between 09:00 and 10:00 $\mathrm{h}$ to minimise any effect of differential burrow emergence behaviour on catch composition (Atkinson \& Naylor 1976) and the effect of capture time on infection prevalence (Field et al. 1998). Monthly samples were taken between October 1999 and September 2000 (inclusive) for the assessment of Hematodinium infection prevalence using the pleopod diagnosis method of Field \& Appleton (1995). Bimonthly samples of lobster tissue were also taken from sub-samples of the catch over the same period and tested for Hematodinium infection using an immunoassay based on Western blotting for parasite antigens as detailed below. The lobsters used were stored alive in a cool, damp environment (usually on ice) following capture for transfer to the laboratory for analysis. Pleopods were viewed using low power light microscopy ( $\times 40$ magnification). The accumulation of agglutinated parasite and hemocyte material was used to assign the infection stage according to Field \& Appleton (1995). Stage 0 is apparently uninfected and Stages 1 to 4 are stages of increasingly severe patent infection.

Tissue preparation and immunoassay conditions. Tissue samples from a standard subset of 60 lobsters (30 each of male and female), diagnosed as Stage 0 by the pleopod method, were prepared for immunoassay diagnosis. Small blocks (ca $2 \mathrm{mg}$ ) of hepatopancreatic tissue were excised, placed into $200 \mu \mathrm{l}$ SDS-sample buffer $(62.5 \mathrm{mM}$ Tris- $\mathrm{HCl} \mathrm{pH} 6.8,12.5 \%$ glycerol, $1.25 \% \beta$-mercaptoethanol) and immediately heated in a water bath at 95 to $100^{\circ} \mathrm{C}$ for $4 \mathrm{~min}$. This process facilitated the rapid and complete denaturation of enzymes in the sample. The denatured samples were then frozen at $-20^{\circ} \mathrm{C}$ until analysis (usually within $1 \mathrm{wk}$ ).

Samples were defrosted immediately before analysis and $10 \mu \mathrm{l}$ aliquots were subjected to discontinuous SDS-PAGE, performed according to the method of Laemmli (1970) with a $12.5 \%$ acrylamide separating gel and a $4 \%$ acrylamide stacking gel. Electrophoresis running conditions were as described by Neil et al. (1993). Following separation of proteins, gels were transferred to a nitrocellulose membrane (Amersham Life Science, Little Chalfont, Bucks, UK) in a buffer of $20 \mathrm{mM}$ Tris, $150 \mathrm{mM}$ glycine and $20 \%$ (v/v) methanol at $100 \mathrm{~V}$ for $45 \mathrm{~min}$ (BioRad, Hercules, CA). Membranes were blocked overnight at $4^{\circ} \mathrm{C}$ in $5 \%(\mathrm{w} / \mathrm{v})$ milk powder in Tris-buffered saline (TBS) $(20 \mathrm{mM}$ Tris base $\mathrm{pH}$ 7.6, $137 \mathrm{mM}$ sodium chloride, 3.8\% (v/v) $\mathrm{HCl}$ 
with $0.1 \%$ Tween 20 and $0.1 \%$ gelatin). After blocking, membranes were rinsed in TBS (pH 7.6) with $0.1 \%$ Tween 20 and $0.1 \%$ gelatin, following which the primary rabbit antibody (anti-Hematodinium lysate-for production protocol see Field \& Appleton 1996) was applied for $4 \mathrm{~h}$ at a dilution of $1 / 1000$ in TBS. Blots were then washed at room temperature 5 times for 10 min each, with vigorous shaking. The secondary antibody (anti-rabbit-horseradish peroxidase conjugate) was then applied at a concentration of 1/1000 in TBS for $1 \mathrm{~h}$ at room tempera-ture and developed using chemiluminescence reagents (Pierce, Rockford, IL) for $5 \mathrm{~min}$ and standard developer and fixer (Kodak, Rochester, NY) onto ECL film (Amersham Life Science). Known Hematodinium-positive and uninfected haemolymph samples were used as controls.

As the hepatopancreas was chosen as the test organ, the method allowed for the detection of latent (tissuebased) and sub-patent (low-level haemolymph parasitaemia) infections. Hematodinium-positive samples were recognised by the presence of multiple-bands or smears due to reaction of numerous parasite proteins with the polyclonal primary antibody. The immunoassay-derived estimate of sub-patent/latent (SPL) infection was used to re-calculate the pleopod-derived prevalence estimate for Hematodinium infection in Nephrops norvegicus, of both sexes, in the original sub-samples.

To test the detection sensitivity of the Western blotting method, Hematodinium parasite cell density in the haemolymph of an infected lobster was determined microscopically. Haemolymph was withdrawn from the base of the fifth pereiopod and then transferred into an Improved Neubauer counting chamber. Hematodinium cells were enumerated according to the method of Baker et al. (1966). Samples of the same haemolymph were diluted to $10 \%$ in SDS-sample buffer, serially 2-fold diluted, and subjected to SDS-PAGE and Western blotting as described above. The sensitivity of the method was defined as the minimal number of parasites that could be detected by the Western blotting technique.

\section{RESULTS}

\section{Severity of infection through the year}

As well as allowing Hematodinium infection prevalence to be assessed at the population level, the pleopod staging method allows assessment of infection severity within individual lobsters (stages of infection 1 to 4$)$. The data presented in Fig. 1 shows the percentage of infected lobsters at the different stages of infection over the whole study period. In the early season (October and November), all infected lobsters captured displayed only very light infections (Stage 1). However, as the season progressed, an increasing proportion of the infected lobsters captured were more severely infected (Stages 2 and 3-4) so that by June and July all infected lobsters captured were severely infected. These data suggest that Hematodinium infection severity is progressive in individual lobsters. Peak infection prevalence occurred in April.

\section{Sensitivity of the Western blot method}

The use of serial dilutions of infected haemolymph, containing a known density of parasites, allowed the sensitivity of the immunoassay to be determined. The
Fig. 1. Percentages of Hematodinium-infected Nephrops norvegicus at each infection stage, as judged by the pleopod staging method, in monthly samples from the Little Cumbrae site between October 1999 and September 2000. Overall monthly infection prevalence $(\%)$ in the catch is given above each bar

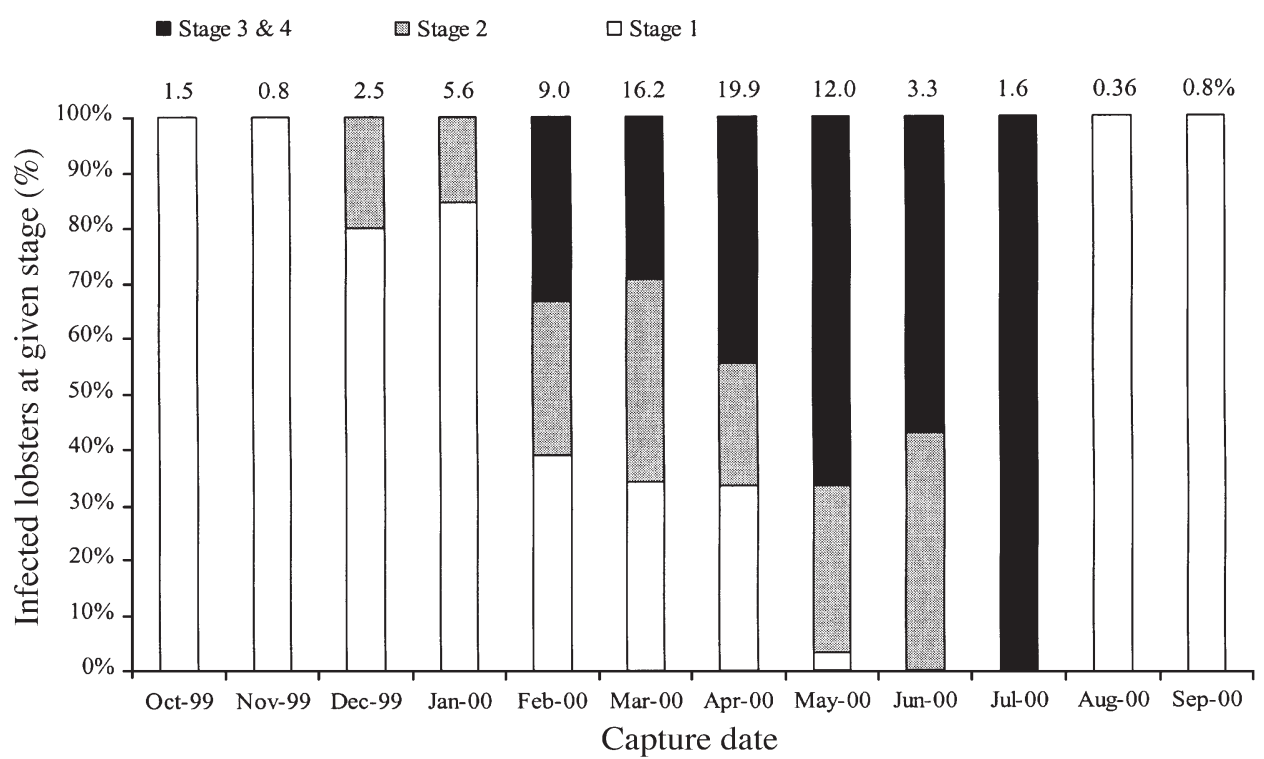




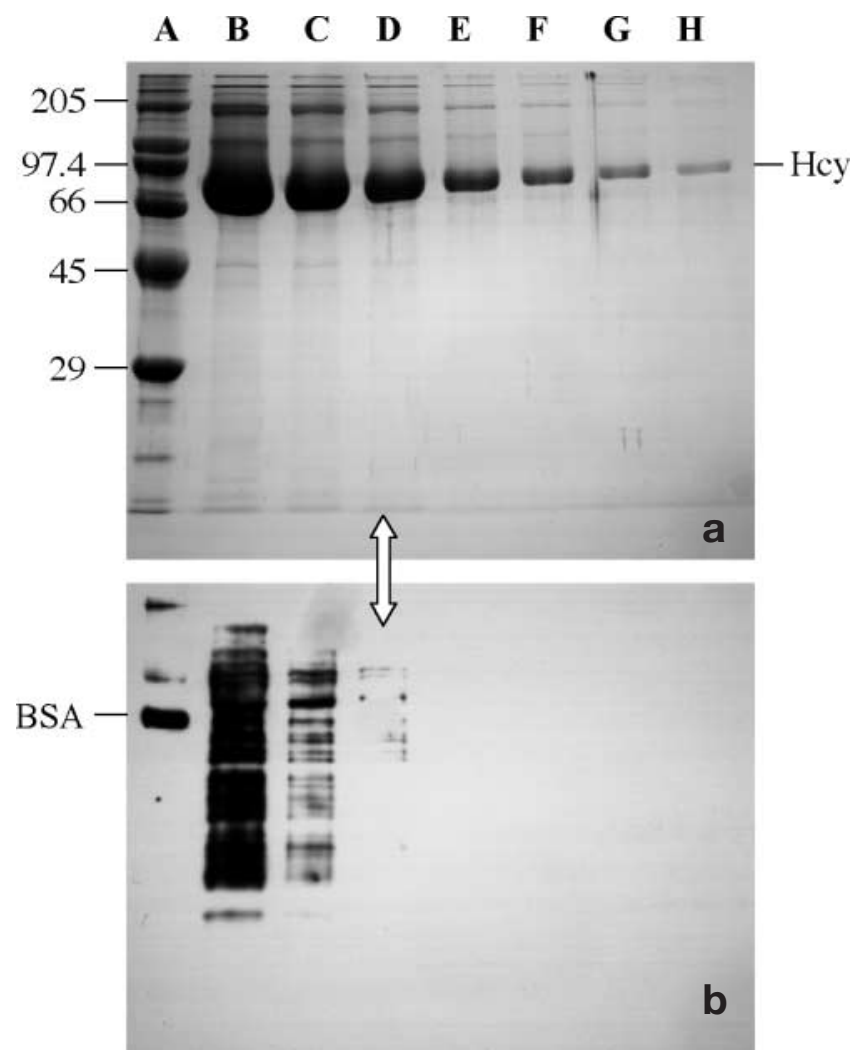

Fig. 2. (a) $12.5 \%$ SDS-PAGE gel of serially 2 -fold dilutedplasma from an Hematodinium-infected Nephrops norvegicus. (b) Western blot of the same serially diluted infected plasma showing reaction of the separated proteins with antiHematodinium primary antibody in Lanes B (815 parasites $\mathrm{mm}^{-3}$ ), C (408 parasites $\mathrm{mm}^{-3}$ ) and D (204 parasites $\mathrm{mm}^{-3}$ ). Numbers on left of gel refer to approximate relative molecular weight. Hcy = plasma haemocyanin sub-units

sensitivity limit was 204 parasites $\mathrm{mm}^{-3}$ of haemolymph (Lane D, Fig. 2). When a greater number of parasites were present, numerous bands were detected with the polyclonal anti-Hematodinium antibody (Lanes B and C), but with fewer parasites no bands were detected. There was also reaction to the $66 \mathrm{kDa}$ protein (bovine serum albumin) and 2 other proteins (molecular masses of $>200 \mathrm{kDa}$ and ca $97 \mathrm{kDa}$ ) in the molecular weight $\left(\mathrm{M}_{\mathrm{r}}\right)$ marker protein mixture (Lane A).

By applying the same method to excised hepatopancreas samples from field-caught lobsters, previously diagnosed as Stage 0 by the pleopod method, subpatent and/or latent infections were detected. Here, infected samples appeared as heavy, multiple-band reactions (see lobster Samples 1, 5, and 8 in Fig. 3). Samples of apparently uninfected lobsters (Samples $2-4,6$ and 7) showed no reaction to the anti-Hematodinium antibody. This both confirms that the antibody does not cross react with host tissues and also that the method clearly distinguishes between infected and uninfected lobsters.

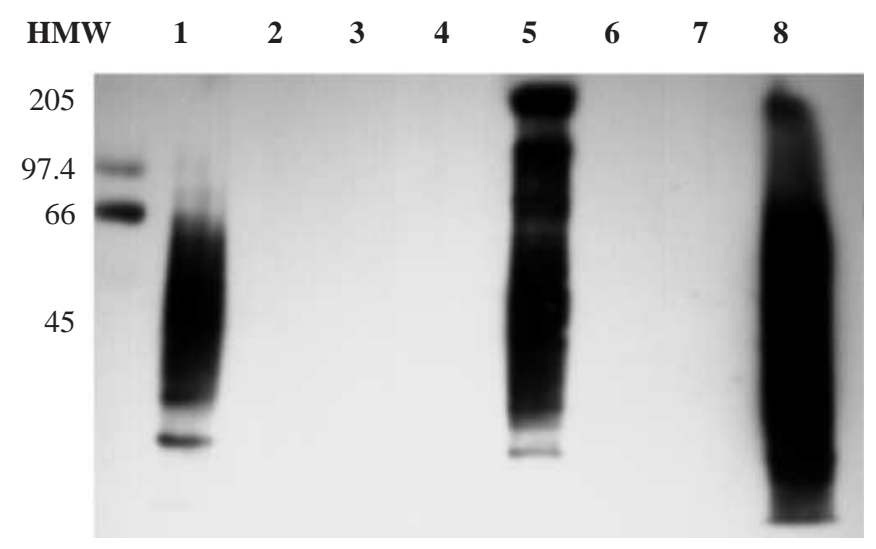

Fig. 3. Western blot of hepatopancreas samples from a typical sub-sample of pleopod-diagnosed Stage 0 lobsters. High molecular weight marker (HMW). Multi-band reaction of parasite proteins to the primary antibody in Lanes 1,5 and 8. No reaction to samples from apparently uninfected lobsters (Lanes 2-4, 6 and 7). Numbers on left of gel refer to approximate relative molecular weight

\section{Incorporation of immunoassay data into pleopod prevalence analysis}

Immunoassay-derived infection prevalence data for latent and/or sub-patent infections were used to recalculate pleopod-derived infection prevalence estimates for the corresponding month. The immunoassay allowed for much earlier detection of infection in female lobsters (October) than was possible with the pleopod method (first detected in December) (Fig. 4a). By December, the immunoassay-derived estimates showed that infection prevalence was dramatically greater (over $25 \%$ ) than the pleopod analysis had suggested (less than $5 \%$ ). A similar situation was revealed with the February samples. By April ('peak season' from pleopod diagnosis $>30 \%$ infection), there were fewer SPL infections. By June, pleopod prevalence had reduced to approximately $5 \%$, and there were no SPL infections. This suggests that following the peak of patent infection in April, there were either no new Hematodinium infections or newly infected lobsters had parasite burdens below the limit of detection with the immunoassay method (Fig. 4a).

A similar pattern in the immunoassay and pleopodderived infection prevalence estimates was also seen for male lobsters (Fig. 4b), though patent infections appeared earlier (October) and overall prevalence at the peak of infection (April) was approximately half that of females.

When the data for immunoassay and pleopodderived infection prevalence were plotted separately, it was possible to examine the epidemiological nature of SPL and patent Hematodinium infection in Nephrops norvegicus. In females, the SPL prevalence rose to a 

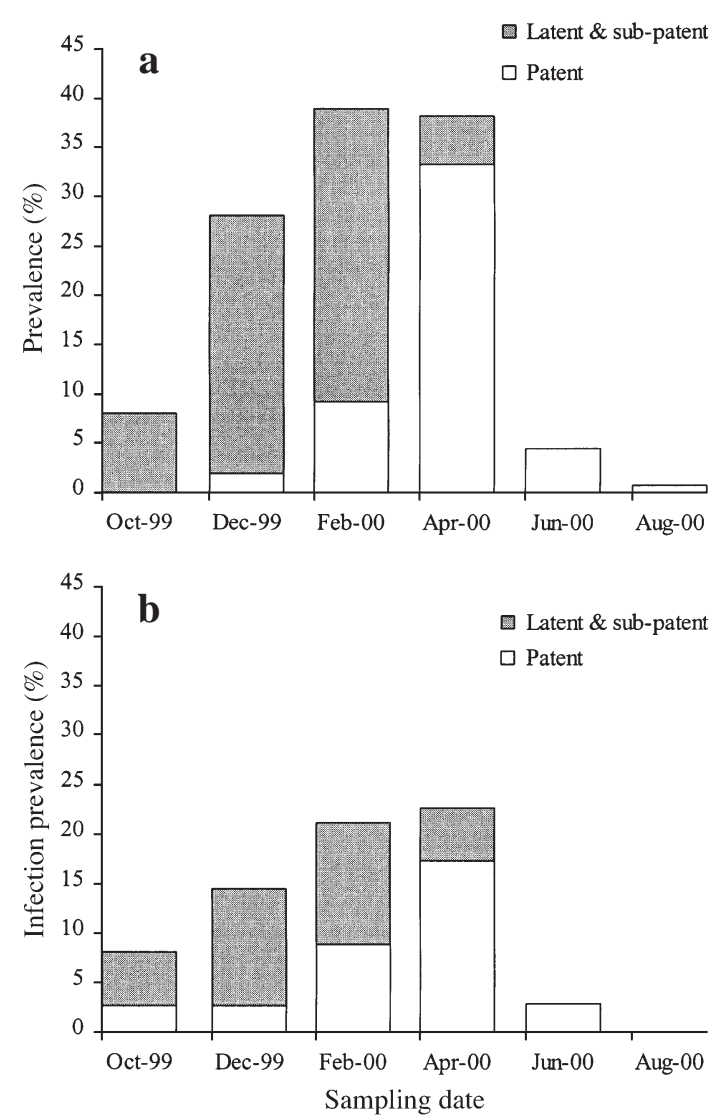

Fig. 4. Immunoassay-corrected Hematodinium infection prevalence estimates for (a) female and (b) male Nephrops norvegicus from the Little Cumbrae site. Immunoassay data (grey bars). Pleopod infection data (white bars)

peak in February and then began to fall (suggesting that all lobsters showing patent infection within a given season were infected by February). Following this peak, SPL infections advanced to a patent state, reaching a peak in April. As shown in Fig. $4 a$, b, when patent infection prevalence was at its highest (April) the prevalence of SPL infection had reduced to very low levels. The decline in SPL infection to zero in June suggests that infections may not have been carried over from one season to the next, but were instead acquired at some point after late summer (shown by the low level of sub-patent infection in October) (Fig. 5). SPL and patent infection in male lobsters showed a similar epidemiological pattern, though here, the overall prevalence was considerably lower than in female lobsters (Fig. 5). The time period between a given level of SPL infection prevalence and the same level of patent infection prevalence (shown by the 'phase-shifted' nature of the prevalence peaks) may indicate the approximate incubation time of the Hematodinium parasite from the SPL to patent state. Data presented here suggest that this time period may

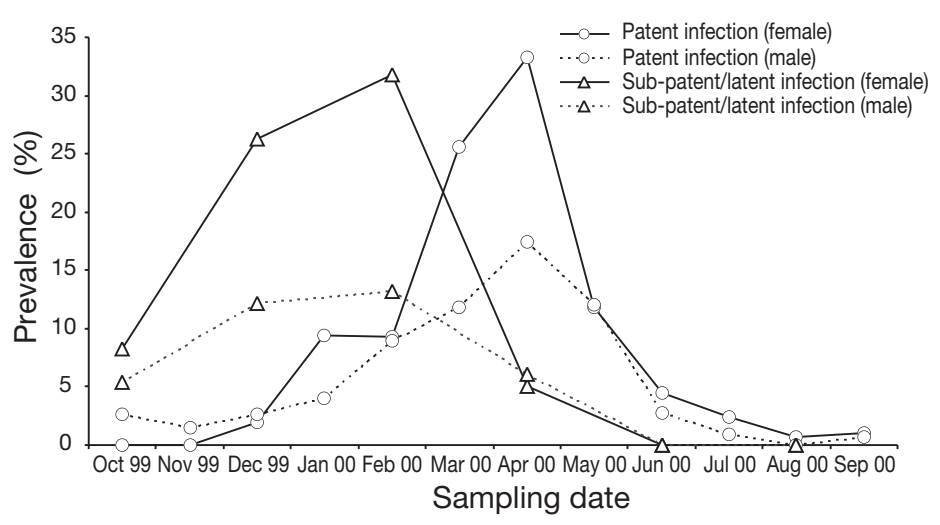

Fig. 5. Immunoassay-derived (latent and sub-patent infections in Stage 0 lobsters) and pleopod-derived (patent) Hematodinium infection prevalence for female and male Nephrops norvegicus

be between 2 and 4 mo. It is important to note that the prevalence of SPL infection was approximately equal to the prevalence of patent infection that followed. This suggests that lobsters carrying a sub-patent or latent infection will display the symptoms of patent infection within the same season (Fig. 5).

\section{DISCUSSION}

In the current study, further development of the IFAT described by Field \& Appleton (1996) into a multi-sample immunoblotting assay has allowed the detection of SPL Hematodinium infections in fieldcaught samples of Nephrops norvegicus. The Western blotting assay detected parasite densities of 204 parasites $\mathrm{mm}^{-3}$ and above. This method is therefore approximately 10 times more sensitive than the pleopod diagnostic method, in which Stage 1 infected lobsters have burdens of over 2000 parasites $\mathrm{mm}^{-3}$ (see Field et al. 1992, Field \& Appleton 1995). The technique worked well for both diluted haemolymph and for tissue samples, with there being no reaction of the polyclonal antibody to $N$. norvegicus material. Reactions between the anti-Hematodinium antibody and the proteins in the $\mathrm{M}_{\mathrm{r}}$ marker probably reflect the presence of antibody against components of the parasite's culture medium (which included fetal calf serum) which would have been present on the surface of injected Hematodinium parasites during the initial production of the antibody (see Field \& Appleton 1996).

Latent Hematodinium infections of Nephrops norvegicus are thought to involve parasites residing in tissues such as the hepatopancreas and muscle (see Appleton \& Vickerman 1998), while in low-level subpatent infections parasites are also present in the haemolymph (Field \& Appleton 1996). As the main purpose of the immunoassay in the current study was 
to detect all infections (latent and sub-patent) not detectable by the pleopod staging method, hepatopancreas samples were used. Immunoblotting of these did not distinguish between latent and sub-patent infections. Hence no distinction was made between subpatent and latent infection states for immunoassayderived prevalence calculations.

The data showed that the pleopod diagnostic method considerably under-estimates the prevalence of Hematodinium infection during the early season, but also that the degree of underestimation is reduced as the main infection season (February to April) progresses. This reduction is likely to be due to the development of latent and sub-patent infections into pleopod-detectable patent infections. The similarity in the amplitude of the SPL (immunoassay-derived) and patent (pleopodderived) infection peaks suggests that all lobsters with a SPL infection within a given season will also express a patent infection within the same season. In addition, data for average patent infection severity (derived from monthly pleopod diagnosis) showed that a steady increase in infection severity occurred as the season progressed. As such, most infected lobsters captured at the end of the season had considerably larger parasite burdens than those captured at the start of the season. Data for infection severity progression are suggestive of a relatively slow incubation of the parasite in the haemolymph, and reinforce previous data which showed that the Hematodinium parasite burden increased by 100fold over a period of $100 \mathrm{~d}$ in the haemolymph of aquarium-held infected lobsters (Appleton et al. 1997). The slow incubation of patent Hematodinium infection in the field may increase the chance of parasite transmission via cannibalism or predation. The increase in parasite number correlates well with the progressive utilization of host tissue and haemolymph storage products (Stentiford et al. 1999, 2000b).

Most studies on Hematodinium infections of decapod crustaceans have proposed a long, asymptomatic latency, followed by a shorter period of parasite proliferation and spore release (Hudson \& Shields 1994). Colonization of a new host may occur shortly after ecdysis, or parasites may remain in the host through the moult (Shields 1992). If infection is acquired within one season and remains in a latent state until the following season, it should be possible to detect the same level of latent infection prevalence out-of-season as patent infection in the following season. In the current study, the increasing SPL prevalence up to February suggests that either acquisition of infection occurs within the same season that full patency develops, or that the immunoblotting technique failed to diagnose very low burdens of parasites outside of the main infection season. Similarly, the reduction in the prevalence of sub-patent infections to zero in June suggests that either Stage 0 lobsters at this time are completely free from infection, or that very low-level latent infections are undetectable using this assay. However, it may be that the parasite burden within the tissues of latently infected lobsters also differs significantly between individuals and over time. Lobsters infected with very low tissue-based parasite burdens would not be detectable with the current immunoassay. Alternatively, upon initial infection, the Hematodinium parasite may reside in different tissues or organs than those tested (see Field \& Appleton 1995, 1996). Further studies, using other tissues and organs are required to resolve this issue.

If acquisition of infection does occur within the same season as patent infection is expressed, transmission is unlikely to be occurring via lesions in the cuticle of newly moulted lobsters as the main moulting season for Nephrops norvegicus is during the spring and early summer (Farmer 1974). In this case, acquisition of parasites is more likely to be occurring by the direct ingestion of vegetative stages or spores of the Hematodinium parasite (Appleton \& Vickerman 1998). Sensitive diagnosis of Hematodinium infection by the use of the polymerase chain reaction (PCR) has been demonstrated (Hudson \& Adlard 1994, 1996). However, no follow-up studies over longer periods have been carried out. Utilization of a sensitive PCR method for the detection of very low parasite burdens is required if issues relating to the latency and transmission of the Hematodinium parasite in N. norvegicus are to be resolved.

In order to make reliable comparisons of Hematodinium infection prevalence between different European Nephrops norvegicus fisheries, the diagnostic method must be standardized and reproducible in the hands of different operators. While the pleopod diagnostic method has some merit for estimating Hematodinium-associated mortality in $N$. norvegicus, the insensitivity of the method, in addition to the subjectivity of assessment between different scorers (Stentiford et al. 2001b), suggests that the pre-season measurement of SPL infections by immunoassay may provide an alternative means of estimating Hematodinium infection prevalence in the field. Additionally, due to the phase-shifted nature of the immunoassay-derived prevalence peak from the pleopod-derived prevalence peak (by a period of 2 to $4 \mathrm{mo}$ ), it is likely that immunoassay-derived prevalence data could be used to predict the level of patent infection level that will appear in the fishery. As such, the immunoblotting technique described here has furthered our knowledge on the epidemiology of Hematodinium infection in $N$. norvegicus and the development of this into a rapid, non-subjective enzyme-linked-immunosorbantassay (ELISA), which utilizes a specific monoclonal antibody, is being pursued. 
Acknowledgements. This work was supported by a contract from the Ministry of Agriculture Fisheries \& Food, United Kingdom (Contract No. CSA 4172, Project code MFO221). The authors thank Mr Mick Parker and the crew of the RV 'Aora' (University Marine Biological Station, Millport) for assistance in the collection and sorting of animals.

\section{LITERATURE CITED}

Appleton PL, Field RH, Vickerman K, Atkinson RJA, Taylor AC, Rogerson A, Neil DM (1997) Mortality of Nephrops norvegicus on the west coast of Scotland. Report to MAFF CSG, March 1997. University of Glasgow

Appleton PL, Vickerman KV (1998) In vitro cultivation and development cycle in culture of a parasitic dinoflagellate (Hematodinium sp.) associated with mortality of the Norway lobster (Nephrops norvegicus) in British waters. Parasitology 116:115-130

Atkinson RJA, Naylor E (1976). An endogenous rhythm and rhythmicity of catches of Nephrops norvegicus. J Exp Mar Biol Ecol 25:95-108

Baker FJ, Silverton RE, Luckock ED (1966) Introduction to medical laboratory technology, 4th edn. Butterworth \& Co Ltd, London

Farmer ASD (1974) Reproduction in Nephrops norvegicus (Decapoda: Nephropidae). J Zool 174:161-183

Field RH, Appleton PL (1995) A Hematodinium-like dinoflagellate infection of the Norway lobster Nephrops norvegicus: observations on pathology and progression of infection. Dis Aquat Org 22:115-128

Field RH, Appleton PL (1996) An indirect fluorescent antibody technique for the diagnosis of Hematodinium sp. infection of the Norway lobster Nephrops norvegicus. Dis Aquat Org 24:199-204

Field RH, Chapman CJ, Taylor AC, Neil DM, Vickerman K (1992) Infection of the Norway lobster Nephrops norvegicus by a Hematodinium-like species of dinoflagellate on the west coast of Scotland. Dis Aquat Org 13:1-15

Field RH, Hills JM, Atkinson RJA, Magill S, Shanks AM (1998) Distribution and seasonal prevalence of Hematodinium sp. infection of the Norway lobster (Nephrops norvegicus) around the west coast of Scotland. ICES J Mar Sci 55:846-858

Hudson DA (1995) Biochemical parameters of the serum of the sand crab, Portunus pelagicus, with reference to the parasitic dinoflagellate, Hematodinium australis. Bull Eur J Fish Pathol 15:202-205

Hudson DA, Adlard RD (1994) PCR-techniques applied to Hematodinium spp. and Hematodinium-like dinoflagellates in decapod crustaceans. Dis Aquat Org 20:203-206

Hudson DA, Adlard RD (1996) Nucleotide sequence determination of the partial SSU rDNA gene and ITS1 region of Hematodinium cf. perezi and Hematodinium-like dinoflagellates. Dis Aquat Org 24:55-60

Hudson DA, Shields JD (1994) Hematodinium australis n. sp., a parasitic dinoflagellate of the sand crab Portunus pelagicus from Moreton Bay, Australia. Dis Aquat Org 19: $109-119$

Editorial responsibility: Carey Cunningham, Aberdeen, Scotland, UK
Laemmli UK (1970) Cleavage of structural proteins during assembly of the head of the bacteriophage T4. Nature 227: $180-185$

Love D, Thomas R, Moles A (1996) Bitter crab hemolymph studies: Indicators of host physiological condition. Symposium on High Latitude Crabs, Alaska Sea Grant College Program, Alsaka, AK-SG-96-02

McAliskey M, Briggs RP (1997) Hematodinium in Irish Sea Nephrops. ICES CM-1997/HH:25

Messick GA (1994) Hematodinium perezi infections in adult and juvenile blue crabs Callinectes sapidus from coastal bays of Maryland and Virginia, USA. Dis Aquat Org 19: $77-82$

Meyers TR, Koeneman TM, Botelho C, Short S (1987) Bitter crab disease: a fatal dinoflagellate infection and marketing problem for Alaskan tanner crabs Chionoecetes bairdi. Dis Aquat Org 3:195-216

Neil DM, Fowler WS, Tobasnick G (1993) Myofibrillar protein composition correlates with histochemistry in fibres of the abdominal flexor muscles of the Norway lobster Nephrops norvegicus. J Exp Biol 183:185-201

Shields JD (1992) Parasites and symbionts of the crab Portunus pelagicus from Moreton Bay, eastern Australia. J Crustac Biol 12:94-100

Shields JD, Squyars CM (2000) Mortality and hematology of blue crabs, Callinectes sapidus, experimentally infected with the parasitic dinoflagellate Hematodinium perezi. Fish Bull 98:139-152

Stentiford GD, Neil DM, Coombs GH (1999) Changes in the plasma free amino acid profile of the Norway lobster Nephrops norvegicus at different stages of infection by a parasitic dinoflagellate (genus Hematodinium) Dis Aquat Org 38:151-157

Stentiford GD, Neil DM, Atkinson RJA, Bailey N (2000a) An analysis of swimming performance in the Norway lobster, Nephrops norvegicus L. infected by a parasitic dinoflagellates of the genus Hematodinium. J Exp Mar Biol Ecol 274:169-181

Stentiford GD, Neil DM, Coombs GH (2000b) Alterations in the biochemistry and ultrastructure of the deep abdominal flexor muscle of the Norway lobster Nephrops norvegicus during infection by a parasitic dinoflagellate of the genus Hematodinium. Dis Aquat Org 42:131-141

Stentiford GD, Neil DM, Atkinson RJA (2001a) Alteration of burrow-related behaviour of the Norway lobster, Nephrops norvegicus (L.) during infection by the parasitic dinoflagellate Hematodinium. Mar Freshw Behav Physiol (in press)

Stentiford GD, Neil DM, Atkinson RJA (2001b) The relationship of Hematodinium infection prevalence in a Scottish Nephrops norvegicus population to season, moulting and sex. ICES J Mar Sci 58:814-823

Taylor AC, Field RH, Parslow-Williams PJ (1996) The effects of Hematodinium sp.-infection on aspects of the respiratory physiology of the Norway lobster, Nephrops norvegicus (L.). J Exp Mar Biol Ecol 207:217-228

Tuck ID, Chapman CJ, Atkinson RJA, Bailey N, Smith RSM (1997) A comparison of methods for stock assessment of the Norway lobster, Nephrops norvegicus, in the Firth of Clyde. Fish Res 32:89-100

Submitted: October 12, 2000; Accepted: March 13, 2001 Proofs received from author(s): September 24, 2001 